\title{
Wybrane kolekcje historyczne z zakresu historii medycyny i farmacji we współczesnych zbiorach muzealnych i bibliotekach naukowych Stambułu - część pierwsza ${ }^{1}$
}

\author{
Selected historical collections in the field of the history \\ of medicine and pharmacy in the contemporary museum \\ collections and scientific libraries of Istanbul. Part one
}

\begin{abstract}
Summary
In the collections of Turkish public scientific institutions, museums and libraries, there are extensive resources of historical artifacts connected thematically with the history of medicine and pharmacy. They include mainly manuscript books in Arabic, Persian, Turkish and also in Greek and Latin, which were gathered in the capital of the Ottoman Empire. The historical and medical collections contain also numerous printed books, including critical editions of the work by the classic authors of Islamic medicine together with their translations into congressional languages. In Istanbul, we can also find numerous examples of various types of devices and equipment used in connection with the treatment and production of medicines. The article consists of two parts. The first part presents the outline of the history of the evelopment of historical collections in Istanbul connected with
\end{abstract}

1 Artykuł powstał w ramach programu badawczego Uniwersytetu Medycznego im. Piastów Śląskich we Wrocławiu nr SUB.D210.21.104. 
the history of medicine and pharmacy. The second part describes selected museum

facilities and collections.

Keywords: history of medicine and pharmacy in Turkey, historical collections of Istanbul

Słowa kluczowe: historia medycyny i farmacji w Turcji, kolekcje historyczne Stambułu

\section{Wprowadzenie}

We współczesnych muzeach, bibliotekach i wyższych uczelniach Stambułu znaleźć możemy bardzo wiele zabytków dawnej kultury naukowej. Dotyczy to wszystkich dziedzin nauki. Ze szczególnym zainteresowaniem należy jednak podejść do zgromadzonych w tym mieście kolekcji dokumentujących dorobek dawnej wiedzy i praktyki w dziedzinie medycyny i farmacji. Historia Stambułu umożliwiła bowiem zgromadzenie $\mathrm{w}$ jednym miejscu zabytków pochodzących $\mathrm{z}$ wielu różnych kultur. W 1453 r. założony jeszcze $\mathrm{w}$ starożytności Konstantynopol został zdobyty przez Turków, którzy przenieśli do niego swoją stolicę 2 . W trakcie walk o miasto uległo zniszczeniu wiele zgromadzonych w nim zabytków, kolekcji i bibliotek, jednak jeszcze $\mathrm{w}$ tym samym roku zaczęło się ich ewidencjonowanie z zamiarem wykorzystania $\mathrm{w}$ tworzeniu potencjału kulturalnego i naukowego nowego stołecznego ośrodka Turków Osmańskich - Stambułu. Już w XV w. wytworzyła się bowiem wśród elity państwowej Imperium Osmańskiego świadomość, zgodnie z którą państwo to uznawało się za kontynuatora tradycji cesarskich Bizancjum. Wiązała się z tym zmiana stosunku do znajdujących się w zdobytym mieście zabytków. Uznano je za elementy własnej historii, a niektóre z nich (jak np. świątynię Mądrości Bożej - Hagia Sophia - z VI w.) uznano za wzorzec własnej architektury sakralnej ${ }^{3}$. Jeszcze przed 1453 r. w historii Konstantynopola odnotowywano jednak poważne straty $\mathrm{w}$ stanie zachowania

${ }^{2}$ C. Imber, Imperium Osmańskie 1300-1659, tłum. P. Zarawska, Wydawnictwo Naukowe PWN, Kraków 2018.

3 A. Kompa, Konstantynopolitańskie zabytki w Stambule, „Acta Universitatis Lodzensis. Folia Historica" 2011, z. 87, s. 125-129. W niniejszym opracowaniu zostały przedstawione losy wszystkich ważniejszych obiektów architektury publicznej, zarówno świeckiej, jak i związanej z kultem religijnym, po przejęciu Konstantynopola przez Imperium Osmańskie. Znajduje się tu również obszerna bibliografia piśmiennictwa na ten temat. 
zgromadzonych w tym mieście zabytków. Występowały one w związ$\mathrm{ku} \mathrm{z}$ walkami o władzę toczonymi wśród bizantyjskich stronnictw politycznych oraz w wyniku klęsk elementarnych (pożary, trzęsienia ziemi). Duże straty w księgozbiorach bibliotek, a także wśród innych zgromadzonych w mieście zabytków odnotowano w latach 1204-1261, gdy na terenie Bizancjum funkcjonowało cesarstwo łacińskie ${ }^{4}$. W tym okresie wywieziono z Konstantynopola nie tylko niektóre relikwie ${ }^{5}$, lecz także wiele cennych książek. Wiele $\mathrm{z}$ nich uległo również $\mathrm{w}$ tym czasie zniszczeniu, szczególnie w 1204 r. Szeregowi uczestnicy wypraw krzyżowych nie zdawali sobie bowiem sprawy z ich znaczenia ${ }^{6}$. W XV w., wobec spodziewanego przejęcia miasta przez Turków, wiele dzieł naukowych zostało wywiezionych z Konstantynopola na zachód Europy przez samych Bizantyjczyków ${ }^{7}$. Kolejne ubytki w zasobach bibliotecznych i muzealnych miały miejsce już w czasach sprawowania władzy przez Turków. Wielka fala wywozu zabytków z Imperium Osmańskiego miała miejsce w XIX w., w tym szczególnie w jego drugiej połowie, i utrzymała się aż do wybuchu I wojny światowej. Jej genezę należy wiązać z modą na orientalizm ${ }^{8}$, a także z silnymi wpływami politycznymi państw zachodnioeuropejskich w Turcji. Władze tego kraju nie były w stanie przeciwdziałać wywozowi zabytków do prywatnych kolekcji i państwowych muzeów Anglii, Francji, Austro-Węgier i Niemiec, gdzie zasiliły tamtejsze zbiory muzealne ${ }^{9}$. Pomimo tych strat i zniszczeń muzea, biblioteki i wyższe uczelnie Stambułu gromadzą

${ }^{4}$ Z. Pentek, Cesarstwo łacińskie 1204-1261. Kolonialne państwo krzyżowców czy Neobizancjum?, Wydawnictwo Poznańskie, Poznań 2004. Tu obszerna bibliografia na temat wypraw krzyżowych i ich wpływu na zabytki Konstantynopola.

${ }^{5}$ Np. św. Jana - przewiezione do kościoła w Amiens we Francji czy św. Marka przewiezione do bazyliki w Wenecji.

${ }^{6}$ H.E. Mayer, Historia wypraw krzyżowych, tłum. T. Zatorski, Biblioteka Historii Kościoła, Wydawnictwo WAM, Kraków 2008. Wśród uczestników walk o Konstantynopol w 1204 r. znajdowało się wielu ludzi nielegitymujących się formalnym wykształceniem. Troska o zachowanie zasobów bibliotecznych nie była dla nich zrozumiała.

7 Stały się one w XV i XVI w. ważnym impulsem rozwoju przyrodoznawstwa w Europie Zachodniej. Por. J. Legowicz, Historia filozofii średniowiecznej Europy zachodniej, Państwowe Wydawnictwo Naukowe, Warszawa 1980, s. 15-28.

${ }^{8}$ E.W. Said, Orientalizm, tłum. W. Kalinowski, wstęp Z. Żygulski jun., Państwowy Instytut Wydawniczy, Warszawa 1991; G.-G. Lemaire, Orientalismus. Das Bild des Morgenlandes in der Malerei. Mit einem Vorwort von Genevieve Lacambre, Tandem Verlag, Potsdam 2010.

${ }^{9}$ Por. np. S. Mutlu, S. Michel, Une Collection de Materie Medicale Ottomane au Sein d'un Musee Univeritaire a Paris, [w:] A. Mat, H. Tekiner, B. Sen (red.), The Exchange of Pharmaceutical Knowledge between East and West. Proceedings 42nd International Congress for the History of Pharmacy 8-11 September 2015, Maestro Advertising Co., Istanbul 2016, s. 517-521. 
współcześnie liczne zabytki związane z historią medycyny i farmacji. Są to zbiory o bardzo dużej wartości, tworzone na przestrzeni wieków. Ich współczesne ekspozycje są oparte na aktualnym standardzie muzealnym, który jest przez ich twórców adaptowany w rozmaitych wariantach, ze świadomością metodologii i metodyki wystawiennictwa oraz celów naukowych i edukacyjnych, którym muzea medycyny i farmacji oraz szeroko pojmowanej kultury medycznej mają służyćc ${ }^{10}$. Z opisywanymi kolekcjami miałam okazję zapoznać się w latach 20032019 dzięki współpracy nawiązanej z prof. dr hab. Arin Namal - kierownikiem Zakładu Historii Medycyny i Etyki Wydziału Lekarskiego Uniwersytetu w Stambule. Dzięki niej było możliwe zapoznanie się także z kolekcjami, które nie są szerzej udostępniane publicznie, a ich zwiedzanie możliwe jest wyłącznie po uzyskaniu zgody ich właścicieli.

Celem niniejszego artykułu jest przedstawienie procesu kształtowania się najważniejszych kolekcji historycznych w Stambule, związanych tematycznie z historią medycyny i farmacji. W pierwszej części artykułu omówię główne etapy historii medycyny i farmacji tureckiej, wraz z dotyczącą je bibliografią. Omówię także proces kształtowania się zbiorów znajdujących się obecnie w Stambule. Moim zamiarem było odtworzenie obu tych procesów w sposób równoległy. Określonemu etapowi samoświadomości historycznej i metodologicznej wśród tureckich historyków medycyny towarzyszył bowiem pewien model prezentowania zbiorów dotyczących historii medycyny i farmacji, które były przez autorów wystaw muzealnych interpretowane w sposób zgodny $\mathrm{z}$ akceptowanym przez nich ujęciem własnej narodowej historii. Główną podstawą źródłową, z której w artykule korzystam, są w związku z tym prace autorów tureckich publikowane w językach kongresowych (głównie niemieckim i angielskim). Pozwalają one odtworzyć samoświadomość historyczną i metodologiczną środowiska tureckich historyków nauki, w tym medycyny i farmacji, wywierająca wpływ na ich koncepcje wystawiennicze. Nie zawsze uwzględnia ona

${ }^{10}$ Por. F. Erbay, The Role of Medical Museum in the Education of Medicine, [w:] A. Musajo-Somma (red.), The 39th International Society of History of Medicine Congress on the History of Medicine 5-10 September 2004, Italia, Bari 2005, s. 99-102; eadem, Istanbul Exhibitions as a Rescue for the History of Medicine, [w:] A.D. Erdemir, S. Erer, Ö. Usmanbas, B. Akgün (red.), 5th Balkan Congress on the History \& Medicine Abstract and Proceedings Book 11-15 October 2011 Istanbul, Nobel Tip Kitabevleri, Istanbul 2012, s. 175-183; Y. Óztürk, A Virtual Historical Museum: the Case of Historical Sihhat Pharmacy (Tarihi Sihhat Eczanesi) in the Faculty of Anadolu University, [w:] A. Mat, H. Tekiner, B. Sen (red.), op. cit., s. 385-389; F. Sezgin, The Istanbul Museum for the History of Science and Technology in Islam (An Overview), Culture Co., Istanbul 2010. 
w dostatecznym stopniu tematy uznawane za interesujące historyków medycyny i farmacji w innych krajach, takie jak udział Polaków w kształtowaniu tureckiego standardu medycyny ${ }^{11}$ czy udział Ormian w tureckiej medycynie i farmacji praktycznej, które uznać należałoby za dość znaczący ${ }^{12}$. Korzystając w swoich analizach głównie z prac autorów tureckich, podążam za ich zainteresowaniami badawczymi. Najważniejszym z nich była kwestia stosunku własnej tradycji medycznej do tradycji zachodnioeuropejskiej. Wokół tego problemu toczyła się większość dyskusji w omawianym w tym artykule piśmiennictwie. Autorzy tureccy wyodrębniają w nim kilka najważniejszych obszarów wpływu na rodzimy standard medycyny i farmacji, podkreślając zarazem, że relacje między medycyną zachodnioeuropejską a muzułmańską przebiegały w obu kierunkach.

W części drugiej artykułu omówię natomiast wybrane przykłady muzeów Stambułu, wzbogacając opis niektórych z nich oryginalnymi fotografiami, wykonanymi przeze mnie podczas kolejnych pobytów w Turcji.

${ }^{11}$ Udział Polaków w tureckim życiu medycznym w czasach Imperium Osmańskiego nie doczekał się jeszcze kompleksowego opracowania w historiografii tureckiej. Według informacji uzyskanych od prof. Arin Namal z Uniwersytetu w Stambule w Bibliotece Uniwersytetu oraz w archiwach Stambułu znajdują się liczne informacje na ten temat, które wymagałyby dopiero opracowania. W polskim piśmiennictwie naukowym znajdują się nieliczne publikacje, które mogą stanowić punkt wyjścia do monografii na ten temat. Por.: J.S. Łątka, Odaliski, poturczeńcy i uchodźcy. Z dziejów Polaków w Turcji, Wydawnictwo Universitas, Kraków 2001 (tu: szczegółowa bibliografia piśmiennictwa o Polakach w Turcji); idem, Słownik Polaków w Imperium Osmańskim $i$ Republice Turcji, wyd. 2 poprawione i uzupełnione, Wydawnictwo Towarzystwo Słowaków, Kraków 2015. Wydane zostały także źródła - wspomnienia polskich lekarek praktykujących w Turcji. Por. S. z Rusieckich-Pilsztynowa, Proceder podróży i życia mego awantur, redakcja i wstęp R. Pollak, tekst i przypisy przygotował M. Pełczyński, Wydawnictwo Literackie, Kraków 1962; T. z Kosmowskich-Krajewska, Pamiętnik, przygotowała do druku H. Czajecka, Krajowa Agencja Wydawnicza, Kraków 1989. Por. też: Doświadczenie Wschodu w XVIII i XIX wieku w biografiach kobiet (na przykładzie Salomei Pilsztynowej, Ludwiki Śniadeckiej i Jadwigi Zamojskiej), „Pamiętnik Literacki” 2018, R. CIX, z. 2, s. 5-27.

12 Udział Ormian w tureckim życiu medycznym w czasach Imperium Osmańskiego także nie doczekał się $\mathrm{w}$ tureckiej historiografii medycyny i farmacji monograficznego opracowania. Według informacji uzyskanych od prof. Arin Namal w archiwach Stambułu znajdują się na ten temat liczne źródła. Ormianie byli bowiem ważnym elementem tureckiego handlu hurtowego z Europą, odbywającego się drogą lądową ze Stambułu do Lwowa, i dalej wzdłuż Wisły do Torunia i Gdańska. Odnogą tego szlaku była droga ze Lwowa na Śląsk, do Wrocławia, Świdnicy i dalej na zachód. Ze względu na brak większej liczby tureckich publikacji na ten temat nie będę omawiała ich wpływu na świadomość historyków medycyny i farmacji w Turcji. Temat ten oczekuje dopiero na opracowanie. Por. R. Yildirim, Y. Ulman, A Look at the Ottoman Social and Medical Modernization through the Life of Dr. Servicen, „Bulgarian Historical Review” 2013, z. 3-4, s. 140-150. 


\section{Kształtowanie się standardu tureckich muzeów historii medycyny i farmacji w kontekście historii medycyny i farmacji tureckiej}

Kolekcje historyczne dotyczące medycyny i farmacji zgromadzone we współczesnym Stambule składają się z wielu rodzajów zabytków. Najstarsze z nich pochodzą z okresu Cesarstwa Wschodniorzymskiego $^{13}$ i Bizancjum ${ }^{14}$. Tureccy historycy medycyny i farmacji, podobnie jak tamtejsi historycy nauk przyrodniczych i techniki, ujmują rodzimy standard przyrodoznawstwa jako kontynuację standardu wypracowanego w okresie grecko-rzymskim. Podkreślają jednakże, że islamska medycyna i farmacja nie były jedynie receptywne wobec starożytnych wzorców greckich i rzymskich, ale uczeni związani z muzułmańskim kręgiem kulturowym wnieśli istotny wkład do dorobku medycyny światowej jeszcze przed pojawieniem się państwa tureckiego ${ }^{15}$. Medycyna islamska z czasów przed utworzeniem Imperium Osmańskiego ${ }^{16}$ jest $\mathrm{w}$ tym ujęciu integralną częścią islamskiego, a następnie tureckiego standardu historii medycyny ${ }^{17}$. Wyprowadzana jest bowiem ze wspólnego i trwałego dziedzictwa kultury i obyczajów ${ }^{18}$, a nie tylko ze wspólnoty światopoglądowej ${ }^{19}$.

${ }^{13}$ Por. O. Lafont, Greek Science at the Centre of the Dialogue between Orient and Occident, [w:] A. Mat, H. Tekiner, B. Sen, op. cit., s. 25-36.

${ }_{14}$ Por. D. Oboleński, The Byzantine Commonwelth Eastern Europe 500-1453, Cardinal, London 1974; W.T. Treatgold, History of Byzantine State and Society, University Press, Stanford 1997.

${ }_{15}$ Por. S. Anagnostu, From East to West: Creation, Transmission and Development of Phyto-Pharmaceutical Knowledge over the Centuries, [w:] A. Mat, H. Tekiner, B. Sen (red.), op. cit., s. 37-48.

${ }_{16}$ Por. B. Płonka-Syroka, Medycyna islamska $w$ świetle średniowiecznych miniatur medycznych, [w:] B. Płonka-Syroka, Ł. Braun (red.), Kultura medyczna isla$m u$, Wydawnictwo DiG, Warszawa 2015, s. 17-56; E. Savage-Smith, Medycyna, [w:] R. Rashed (red.), Historia nauki arabskiej, t. 3, Technika, alchemia, nauki przyrodnicze $i$ medycyna, tłum. J. Kozłowska, K. Pachniak, Wydawnictwo Dialog, Warszawa 2005, s. 202-203; P.E. Pormann, E. Savage-Smith, Medieval Islamic Medicine, University Press, Georgetown 2007.

17 Por. M. Shefer-Mossensohn, Ottoman Medicine: Healing and Medical Institution, 1500-1700, State University of New York, Albany 2009.

${ }_{18}$ Por. A. Mazaheri, Życie codzienne muzułmanów w średniowieczu (wiek X-XIII), tłum. E. Bąkowska, Państwowy Instytut Wydawniczy, Warszawa 1972; B. Stępniewska-Holzer, Życie codzienne na Bliskim Wschodzie w XIX wieku, Państwowy Instytut Wydawniczy, Warszawa 2002.

${ }_{19}$ Por. K. Armstrong, Krótka historia islamu, tłum. J. Włodarczyk, Wydawnictwo Dolnośląskie, Wrocław 2004; U. Haarman, P. Bachmann (red.), Die islamische Welt zwischen Mittelalter und Neuzeit. Festschrift für Hans Robert Roemer zum 65 Geburtstag, Ergon Verlag, Beirut-Wiesbaden 1979. 
Dla tureckich historyków medycyny i farmacji charakterystyczne jest wyróżnianie $\mathrm{w}$ islamskiej tradycji leczniczej dwóch odrębnych nurtów, należących do odmiennych kulturowych porządków, które można scharakteryzować jako obszar tzw. kultury wysokiej i obszar kultury plebejskiej, ludowej. W pierwszym z obszarów przyjmuje się za naturalne wywodzenie islamskiej, a następnie tureckiej tradycji medycznej z grecko-rzymskiego standardu medycyny oficjalnej. Był on przejmowany od pojawienia się islamu w VII w. n.e. i z powodzeniem rozwijany przez autorów arabskich, tadżyckich, perskich, a także żydowskich, żyjących w państwach rządzonych przez muzułmańskie dynastie ${ }^{20}$, a następnie uczonych tureckich. Z praktyki medycznej świadczonej zgodnie z zasadami tego nurtu korzystali przeważnie członkowie zamożnych warstw społecznych oraz ludność miejska.

W lecznictwie islamskim na wsi i w warstwach plebejskich istniał (i współcześnie nadal istnieje) obszar równoległej praktyki medycznej, określany jako „medycyna proroka” ${ }^{21}$. Jest to standard oparty na podstawach supranaturalistycznych, w którym diagnostyka i terapia są oparte w sposób bezpośredni na źródłach islamskiej wiary, tj. pismach proroka Mahometa. Oparta na tym standardzie praktyka wolna jest od wpływów medycyny grecko-rzymskiej. Bogate są w niej natomiast lokalne tradycje samolecznicze, oparte na bliskowschodniej i afrykańskiej florze i faunie. W tureckich muzeach historii medycyny i farmacji nurt „medycyny proroka” nie znajduje odzwierciedlenia w ich zbiorach. Zalicza się go bowiem do obszaru medycyny ludowej, który jest przedstawiany w muzeach etnograficznych. Podstawą tego podziału jest fakt, iż standard medycyny ludowej zawiera liczne elementy paranaukowe ${ }^{22}$.

W tureckim muzealnictwie medycznym medycyna islamska definiowana jest jako praktyka naukowa, oparta na tradycjach teoretycznych i terapeutycznych wyprowadzanych ze standardu nauk przyrodniczych wielu krajów i kultur (w ich historycznie zmiennym

${ }^{20}$ Por. Maimonides, On Asthma. A Paralell Arabic-English text edited, translated and annotated by Gerrit Bos, Young University Press, Brigham 2002; M.W. Mönich, Drug Therapy and Rhazes (865-925): Cultural Heritage and Innovation, [w:] A. Mat, H. Tekiner, B. Sen (red.), op. cit., s. 403-408. Por. też: S.S. Kottek, Maimonides (11381204) über Naturheilkunde, [w:] C.-P. Heidel (red.), Naturheilkunde und Judentum. Medizin und Judentum, t. 9, Mabuse Verlag, Frankfurt am Main 2008, s. 111-118.

${ }^{21}$ Por. O. Kotynia, Lekarstwa stosowane $w$ medycynie proroka, [w:] B. PłonkaSyroka, Ł. Braun, op. cit., s. 137-149.

${ }^{22}$ Por. B. Stern, Medizin, Aberglaube und Geschlechtsleben in der Türkey. Mit Berücksichtigung der moslemischen Nachbarländern und der ehemaligen Vasallenstaaten, H. Barsdorf Verlag, Berlin 1903. 
standardzie), z których czerpane są różnorodne wzorce naukowe, przystosowane do użytku przez muzułmanów ${ }^{23}$. W związku z takim określeniem profilu muzeów i kolekcji zbiorów z zakresu historii medycyny i farmacji ich ważną częścią są rękopisy medyczne, które aż do końca XVIII w. były w Państwie Osmańskim kopiowane i udostępniane uczniom lokalnych szkół medycznych. Muzea Stambułu posiadają bogate zbiory takich rękopisów. Są to oryginalne dzieła jednego autora, np. Awicenny, albo anonimowe wypisy z dzieł wielu autorów grecko-rzymskich, z obszernymi komentarzami dodanymi przez autorów islamskich. Rękopisy te są spisane zarówno w języku arabskim, jak i tureckim oraz perskim. Wśród dzieł naukowych z zakresu medycyny mających współcześnie status starodruków znajdują się także liczne książki importowane z Europy. Tych wydanych od początku XVI do końca XVIII w. jest stosunkowo niewiele (nauczanie medycyny i farmacji opierało się bowiem w Turcji w tym okresie na rodzimych rękopisach), ale od początku XIX w. ich liczba zaczyna szybko wzrastać. Od lat 30. XIX w. jest to już wzrost skokowy, w związku z zaczętym $\mathrm{w}$ tym okresie przyspieszonym procesem modernizacji tureckiej medycyny i farmacji w nawiązaniu do wzorów zachodnioeuropejskich.

Stambulskie kolekcje muzealne odzwierciedlają wieloetniczny oraz wielokulturowy standard medycyny praktycznej istniejący w Imperium Osmańskim od 1453 r., tj. od powstania tego państwa na gruzach Bizancjum, do XVIII w. Wśród lekarzy-obcokrajowców praktykujących w Imperium wyróżniali się liczebnie lekarze żydowscy ${ }^{24}$. Wielu z nich przybyło do Turcji w końcu XV w., gdzie znaleźli schronienie przed prześladowaniami w państwie hiszpańskim ${ }^{25}$. Imperium Osmańskie przyjmowało także Żydów aszkenazyjskich, przybywających tu z Europy Środkowej i Wschodniej w XVIII i XIX w. Powstała w ten sposób w Turcji liczna i wpływowa mniejszość, spośród której wywodziło się wielu lekarzy i tłumaczy dzieł medycznych. W drugiej

${ }^{23}$ Por. D. Ceykan, S. Sevumli, Some Examples of „Multinational” Charakter of Ottoman Medical Education and Service, [w:] A.D. Erdemir, S. Erer, Ö.Usmanbas, B. Akgün (red.), op. cit., s. 69-72. Por. też: P.B. Lewicka, Medicine for Muslims? Islamic Theologians, Non-Muslim Physicians and the Medical Culture of the Mamluk Near East, "Annemarie Schimmel Kolleg Working Paper” 2012, nr 03.

${ }^{24}$ Por. H. Ojalvo, Ottoman Sultans and Their Jewish Subjects, http://www.usmessageboard.com/threads/ottoman-sultans-and-their-jewish-subjects.30429/ [dostęp: 24.06.2021]; A. Namal, Die Stellung der Juden in der osmanischen Geschichte der Medizin und Spuren ihrer heilkundischen Tätigkeit, [w:] C.-P. Heidel (red.), Naturheilkunde und Judentum. Medizin und Judentum, t. 9, Frankfurt am Main, Mabuse-Verlag, 2008, s. 87-110.

${ }^{25}$ Imperium Osmańskie przyjęło w tym okresie ok. 200 tys. emigrujących z Hiszpanii Żydów sefardyjskich. 
połowie XVIII i w początkach XIX w. Imperium Osmańskie weszło $\mathrm{w}$ bliższe kontakty $\mathrm{z}$ medycyną zachodnioeuropejską. Tureckie elity władzy uznały ją za bardziej skuteczną od rodzimej i zdecydowały się przeprowadzić jej modernizację według wzorów europejskich ${ }^{26}$. Czerpano te wzorce $\mathrm{z}$ wielu różnych krajów, upowszechniając $\mathrm{w}$ Turcji wpływy francuskie ${ }^{27}$, greckie ${ }^{28}$, włoskie ${ }^{29}$, angielskie ${ }^{30}$, austriackie ${ }^{31}$ i niemieckie ${ }^{32}$. Od lat 30 . XIX w. w modernizacji medycyny tureckiej zaczęły stopniowo przeważać wzorce austriackie i niemieckie, które na przełomie XIX i XX w. stały się dominujące.

Proces modernizacji medycyny tureckiej według wzorców zachodnioeuropejskich był kontynuowany po likwidacji Imperium Osmańskiego i przekształceniu państwa tureckiego w Republikę Turecką (1923). Przywódca państwa tureckiego Mustafa Kemal Atatürk pragnął stworzyć nowoczesne państwo narodowe, o sprawnych służbach publicznych i wydajnym systemie medycyny publicznej. Skorzystał w tym zakresie ze wzorów niemieckich, wypracowanych w latach 80 . XIX w. w okresie rządów kanclerza Ottona von Bismarcka. Nadał jednak systemowi medycyny publicznej w Turcji oblicze bardziej etatystyczne. W latach 1933-1945 recepcja standardu współczesnej niemieckiej nauki akademickiej w Turcji uległa dodatkowemu wzmoc-

${ }^{26}$ Por. R. Dramur, La pratique de la Pharmacie et de la médecine au 19éme siècle aux palais de l'Empire Ottoman, [w:] A. Mat, H. Tekiner, B. Sen (red.), op. cit., s. 115-118; M. Nicolas, La Pharmacie d'Officine Ottomane, [w:] A. Mat, H. Tekiner, B. Sen (red.), op. cit., s. 245-257.

27 Por. B. Sen, M. Nicolas, A. Mat, Les Relations Academiques en Pharmacie entre la France et la Turquie, [w:] A. Mat, H. Tekiner, B. Sen (red.), op. cit., s. 559-562.

${ }_{28}$ Por. Th. Kyrkoudis, C. Soteriadu, Pharmacy at the Crossroads of Trade, Science and Cilivilisation in Istanbul, [w:] A. Mat, H. Tekiner, B. Sen (red.), op. cit., s. 441-447.

${ }^{29}$ Por. R. Dramur, The Medicine Chest in the National Place at Dolmabahce, [w:] 12nd Iternational Congress on the Turkish History of Medicine 10-13 December 2012, Istanbul University, Istanbul 2013, s. 74.

${ }^{30}$ Por. J. Musiatewicz, Lekarze w czasach przemian. Dziewiętnastowieczni egipscy absolwenci europejskich uczelni medycznych, [w:] B. Płonka-Syroka, Ł. Braun (red.), op. cit., s. 77-91.

${ }^{31}$ Por. A. Terzioglu, Die Verdienste der Österreichischen Ärzte, [w:] E. Lesky (red.), Wien und Weltmedizin, Böhlau Verlag, Wien-Köln-Graz 1974, s. 143; A. Terzioglu, E. Lucius (red.), Österreichisch-Türkische Medizinische Beziehungen. Berichte des Symposiums von 28. und 29. April 1986 in Istanbul, University of Istanbul, Istanbul 1987; A. Kernbauer, Die Beziehungen österreichischer Universitäten, im besonderen jener von Prag und Graz, zur Universität Istanbul, [w:] A. Terzioglu (red.), Proceedings of the International Symposium: Istanbul University and the European Universities on the Occasion at the 550th Anniversary of the Foundation of Istanbul University, University of Istanbul, Istanbul 2004.

${ }_{32}$ Por. B. Sen, Deutsch-Türkische Beziehungen in der Pharmazie, [w:] A. Mat, H. Tekiner, B. Sen (red.), op. cit., s. 349-355. 
nieniu. Państwo tureckie przyjęło bowiem w tym okresie dużą grupę uczonych żydowskiego pochodzenia, którzy wyemigrowali z III Rzeszy. Znaleźli oni zatrudnienie na uniwersytetach w Stambule i w Ankarze, a także $w$ innych tureckich ośrodkach akademickich ${ }^{33}$, przyczyniając się w sposób znaczący do modernizacji tureckiej medycyny i farmacji akademickiej. Po II wojnie światowej niektórzy uczeni z tej grupy powrócili do Niemiec lub osiedlili się w nowo powstałym państwie Izrael, jednakże wielu związało się z Turcją na stałe, zajmując do końca lat 60. XX w. stanowiska kierownicze w wielu tureckich instytucjach naukowych i wywierając poważny wpływ na standard, i profil prowadzonych w nich badań.

Kolejny etap $\mathrm{w}$ historii medycyny i farmacji w Turcji zaczął się w latach 70. XX w. W tym czasie nastąpiły liczne nowe inwestycje w wyższe szkolnictwo państwowe o profilu medycznym. Stworzono też nowe szpitale publiczne i zmodernizowano działające w nich apteki. Wymiana sprzętów, z których korzystano w instytutach naukowych, szpitalach i aptekach, stworzyła korzystne okoliczności dla przekazywania wielu z nich do kolekcji muzealnych. Zostały w ten sposób uzupełnione zbiory już istniejących placówek, pochodzące z XIX w., a także zostały utworzone nowe kolekcje historyczne, złożone w dużej części ze sprzętów, mebli, książek i dokumentów pochodzących z XX stulecia. Specyfiką tureckich placówek muzealnych związanych tematycznie $\mathrm{z}$ historią medycyny i farmacji jest duża liczba znajdują-

33 Por. J. Cremer, H. Przytula, Exil Türkey. Deutschsprächige Emigranten in der Türkey 1933-1945, München b.r.; A. Reisman, Turkey's Modernization. Refuges from Nazism and Atatürks Vision, Washington DC, New Academia Publishing, 2006; P. Schwarz, Notgemeinschaft. Zur Emigration deutscher Wissenschaftler nach 1933 in die Türkey, opracowanie i wstęp H. Peukert, Marburg, Metropolis Verlag, 1995A. Namal, Beiträge jüdischer Wissenschaftler in den vorklinischen Fächern der Mediin bei der türkischen Universitätsreform von 1933, [w:] A. Scholz, C.-P. Heidel (red.), Emigrantenschicksale. Einfluss der jüdischen Emigranten auf Sozialpolitik und Wissenschaft in den Aufnahmeländern, Medizin und Judentum, t. 7, Mabuse-Verlag, Frankfurt am Main 2004, s. 83-97; eadem, Zwischen Emigration aus dem NS-Einflussbereich und Ankunft in Palästina bzw. Israel: Jüdische Wissenschaftler an der Universität Istanbul, [w:] C.-P. Heidel (red.), Der Einfluss des Zionismus auf Medizin und Gesundheitswesen, Medizin und Judentum, t. 8, Mabuse Verlag, Frankfurt am Main 2006, s. 121-145; eadem, Emigranten im Gesundheitswesen im Rahmen der türkischen Universitätsreform von 1933, [w:] R. Pfrepper (red.), Medizin-, Pharmazie- und Wissenschaftsgeschichte vom Mittelalter bis zur Gegenwart. Festschrift für Ingrid Kästner zum 65 Geburtstag, Shaker Verlag, Aachen 2007, s. 351-354; eadem, Die Leipzigerin Dr. Cäcilie Leuchtenberg (geb. Nussenow) übernimmnt eine Stelle an der medizinischen Fakultät der Universität Istanbul - Kurzer Zwischenhalt in einem von Migration geprägtem Leben, [w:] B. Płonka-Syroka (red.), Człowiek, natura, kultura - studia z historii medycyny i farmacji społecznej, Studia Humanistyczne Wydziału Farmaceutycznego Akademii Medycznej we Wrocławiu, t. 2, Wrocław 2009, s. 441-456. 
cych się w nich eksponatów pochodzących z Europy, wyprodukowanych w XIX i pierwszej połowie XX w., a następnie importowanych do Turcji. Kolekcje te dokumentują raczej „europejski standard historii medycyny i farmacji w Turcji” niż „turecki standard medycyny” jako taki. Są wyrazem przyspieszonego przystosowywania się tureckiej medycyny i farmacji do europejskiego standardu klinicznego. Proces ten odbywał się przy znaczącym udziale kadry naukowo-dydaktycznej złożonej z uczonych zachodnioeuropejskich.

W latach 80. XIX w. zaczęto tworzyć w Turcji państwowe kolekcje zbiorów dokumentujących historię medycyny i farmacji islamskiej. Składają się na nie eksponaty pochodzące sprzed okresu forsownej i przyspieszonej europeizacji medycyny akademickiej w Turcji. W stambulskich kolekcjach o takiej charakterystyce znajdują się w związku z tym bardzo zróżnicowane eksponaty, które zostaną przeze mnie omówione w drugiej części tego artykułu.

Odrębne miejsce wśród stambulskich muzeów związanych tematycznie z historią medycyny i farmacji zajmuje Muzeum Hammamu, stworzone przy Uniwersytecie Stambulskim ${ }^{34}$. Jego koncepcja jest zgodna z omówionym powyżej standardem, w którym historię medycyny tureckiej przedstawia się $\mathrm{w}$ kontekście nauki europejskiej jako kontynuację klasycznego, grecko-rzymskiego standardu medycyny. Turecka hydroterapia realizowana $\mathrm{w}$ formie hammamu ukazywana jest jako rodzimy, oryginalny wkład do lecznictwa i profilaktyki, a zarazem jako kontynuacja dorobku starożytnej hydroterapii. Teoretyczną podstawą korzystania $\mathrm{z}$ hammanu była bowiem starożytna patologia humoralna, a stosowane tam praktyki miały nie tylko znaczenie higieniczne, lecz także profilaktyczne i lecznicze, dzięki wywieraniu pozytywnego wpływu na równowagę humoralną przez ułatwienie ich przepływu oraz umożliwienie usunięcia skażonych humorów ${ }^{35}$.

${ }^{34}$ Por. F.G. Kadioglu, S. Nazik, S. Kadioglu, Antakyali bilge hekimin Hamam kitabi, Büyüksehir Belediesi Yayinlari, Hatay 2018; A. Namal, Türkish baths in history and their place in daily life, [w:] B. Płonka-Syroka, A. Kaźmierczak, S. Jandziś, A. Syroka (red.), Tradycje i perspektywy rozwoju kultury uzdrowiskowej w Iwoniczu-Zdroju w kontekście europejskim, Kultura uzdrowiskowa w Europie, t. 10, Oficyna Wydawnicza Arboretum, Wrocław 2018, s. 121-133; C.G. Cantay, Hamman - Thermal Spring (Terms, Architekture, Bathing, Healing), [w:] A. Namal, A.D. Erdemir, B. Płonka-Syroka (red.), Tarihte Saglik ve Su Kültürü /Gesundheit und Wasserkultur/ Health and Water-Culture in History, Istanbul Medical Saglik ve Yayincilik Hiz. Tic. Ltd, Istanbul 2016, s. 53-72.

35 Por. N. Sari, Hydrotherapy as descripted in Ottoman Medical Manuscripts, [w:] A. Namal, A.D. Erdemir, B. Płonka-Syroka (red.), Saglik ve Su Kültürü/ Gesundheit und Wasserkultur / Health and Water-Culture, Birinci Baski, Istanbul 2014, s. 161-169; H. Özturk, Turkish Baths in the Travel Book of Evlia Celebi: The City of Istanbul, [w:] A. Namal, A.D. Erdemir, B. Płonka-Syroka (red.), Tarihte Saglik ve Su Kültürü..., op. 
We współczesnych placówkach uniwersyteckich Stambułu znajdują się obszerne zbiory tematycznie związane $\mathrm{z}$ obszarem historii medycyny i farmacji. Są to przede wszystkim książki - rękopisy i starodruki. Większość z nich jest udostępniana wyłącznie pracownikom naukowym i studentom, za okazaniem legitymacji. Niektóre kolekcje można zwiedzić tylko po uzyskaniu specjalnego zezwolenia, po wcześniejszym ustaleniu terminu $\mathrm{z}$ kierownikiem gromadzącej je placówki. Tego typu kolekcje, gromadzące archiwalia i rękopisy, są udostępniane jednakże tylko pracownikom naukowym o udokumentowanym statusie, zatrudnionym $\mathrm{w}$ instytucjach naukowych lub realizującym programy naukowe w ramach grantów. Ograniczenie dostępu do kolekcji jest motywowane dbałością o stan zachowania zbiorów. W niektórych bibliotekach można jednak zamówić (odpłatnie) zdigitalizowane kopie źródeł i opracowań krytycznych. W innych bibliotekach uniwersyteckich ich zasoby biblioteczne podlegają właśnie digitalizacji i w przyszłości będzie można uzyskać do nich dostęp online. Regułą w przypadku korzystania z książek naukowych i kopii starodruków medycznych jest w stambulskich bibliotekach ich czytanie na miejscu. Tylko w niektórych bibliotekach można wypożyczać nowsze piśmiennictwo naukowe. Zamówień można dokonywać drogą elektroniczną lub na miejscu. Czas trwania realizacji zamówienia jest krótki, od 15 minut w przypadku opracowań do 1 dnia w przypadku starodruków udostępnianych na miejscu. Do dyspozycji naukowców i studentów pozostaje nowoczesny i rozbudowany system kopiowania źródeł i piśmiennictwa. Korzystanie z niego jest jednak odpłatne ${ }^{36}$.

\section{Kształtowanie się podstawowego zasobu bibliotek naukowych w Stambule i kolekcji naukowych związanych tematycznie $z$ historią medycyny i farmacji}

Podczas omawiania kolejnych etapów kształtowania się zasobów bibliotecznych i muzealnych państwowych instytucji naukowych

cit., s. 73-78; E. Alkan, Current Reflexions on the Turkish Bath Culture, [w:] A. Namal, A.D. Erdemir, B. Płonka-Syroka (red.), Tarihte Saglik ve Su Kültürü..., op. cit., s. 211218; E. Gültekin, Geschichte der modernen Hydrotherapy in der Türkey mit einigen originalen Beiträgen, [w:] A. Namal, A.D. Erdemir, B. Płonka-Syroka (red.), Tarihte Saglik ve Su Kültürü..., op. cit., s. 15-26; D. Baran, Turkish Bath in the Romanian Principalites, [w:] A.D. Erdemir, S. Erer, Ö. Usmanbas, B. Akgün (red.), 5th Balkan Congress on the History \& Ethics of Medicine 11-15 October 2011 Istanbul. Abstracts and Proceeding Book, Nobel Tip Kitabevleri Ltd, Istanbul 2012, s. 311-320.

${ }^{36}$ Por. E. Piotrowska, R.M. Zając, Biblioteki w Stambule, „Elektroniczne Czasopismo Biblioteki Głównej Uniwersytetu Pedagogicznego w Krakowie” 2015, nr 7, s. 1-10. 
w Stambule nie sposób jest, ze względu na ich ogromną liczebność, wskazać na pochodzenie każdego z ich elementów. W niniejszej części artykułu chciałabym skupić się wyłącznie na ukazaniu ogólnych kierunków, z których pochodzą znajdujące się obecnie w tych zasobach elementy. Czytelników zainteresowanych bardziej szczegółowymi informacjami odsyłam do Działów Informacji Naukowej stambulskich instytucji muzealnych i akademickich.

Najcenniejszym elementem stambulskich zbiorów historycznych związanych z medycyną i farmacją są rękopisy i starodruki. Pochodzą one z wielu źródeł. Po zdobyciu Konstantynopola przez sułtana Mehmeta II w 1453 r., te, które ocalały po zaciętych walkach o miasto, w których wiele zasobów bibliotecznych uległo zniszczeniu, zostały przejęte do nowo tworzonych bibliotek prywatnych, należących do dynastii panującej, rodzin arystokratycznych oraz instytucji naukowych i religijnych. Księgozbiory te liczyły setki tysięcy książek rękopiśmiennych, pochodzących z okresu kilkunastu stuleci. Były spisane po łacinie i po grecku. Stały się w XV w. główną podstawą kształtowania się nowożytnego standardu medycyny i farmacji tureckiej.

Założyciel miasta - Konstanty Wielki - stworzył w IV w. w Konstantynopolu szkołę wzorowaną na akademii ateńskiej i Muzeum w Aleksandrii ${ }^{37}$. Szkoła ta, zwana Kapitolonem, mieściła się przy Forum Tauri, a pod otaczającymi ów rynek krytymi portykami prowadzono nauczanie, podobnie jak w Atenach. Przy szkole Kapitolon działali liczni kopiści dzieł naukowych, których zadaniem było stworzenie w Konstantynopolu (na wzór Aleksandrii) zbioru najważniejszych dzieł naukowych świata śródziemnomorskiego. Biblioteka bardzo szybko się rozrastała. Już w drugiej połowie IV w. Biblioteka Królewska w Konstantynopolu, założona przez cesarza, liczyła ok. 120 tysięcy woluminów. W $474 \mathrm{r}$. jej budynek został zniszczony przez pożar. Ocalałe z pożaru zasoby rękopisów zostały przeniesione do innych bibliotek miasta. W 425 r. cesarz Teodozjusz II stworzył w Konstantynopolu kolejną szkołę o charakterze akademii. Ona także posiadała obszerną bibliotekę. W 463 r. konsul Flawiusz Studius założył w Konstantynopolu klasztor Studion, pod wezwaniem św. Jana Chrzciciela. Klasztor

${ }^{37}$ Por. T. Sinko, Literatura grecka, t. 3, cz. 2, Wydawnictwo PAU, Kraków 1954, s. 65-66. Informacje dotyczące bibliotek i zbiorów manuskryptów Konstantynopola i Stambułu zaczerpnęłam też z licznych stron internetowych dotyczących historii tego miasta w czasach rzymskich, bizantyjskich, imperialnych i współczesnych. Ponieważ występowały tam one w postaci bardzo rozproszonej, a same strony były poświęcone zagadnieniom bardzo odległym od historii nauki, nie wymieniam $\mathrm{w}$ tym artykule bibliografii materiałów internetowych. 
był nie tylko jednostką religijną, lecz także naukową. Zgromadzono w nim następną ogromną bibliotekę rękopisów naukowych, dla której organizacji wzorcem było Muzeum w Aleksandrii. Obszerne biblioteki prywatne posiadali także cesarze bizantyjscy. Jedna z nich znajdowała się $\mathrm{w}$ pałacu położonym $\mathrm{w}$ dzielnicy Bukoleon nad cieśniną Bosfor. W latach 607-610 patriarcha Tomasz I założył w swoim pałacu Bibliotekę Patriarchatu Konstantynopolskiego. W 780 r. została ona zniszczona przez pożar, odbudowano ją jednak i wznowiła działalność. W 842 lub 849 r. założono w Konstantynopolu kolejną szkołę wyższą, zwaną Magnaurą, od łacińskich słów Magna Aula, odnoszących się do obszernego budynku, w którym prowadziła działalność. Szkołę tę zwano też Athenaeum, aby podkreślić pierwowzór, do którego się odwoływała. Około 1030 r. cesarz Roman III założył następną wielką bibliotekę naukową w Konstantynopolu. Znajdowała się w klasztorze Peribleptu, nieopodal klasztoru Studion. Wszystkie wielkie biblioteki Konstantynopola funkcjonowały do 1204 r., kiedy w wyniku walk o miasto doznały zniszczenia (por. przypis 4 do niniejszego artykułu). Część zbiorów bibliotecznych uległa wówczas spaleniu (np. wielka biblioteka w pałacu cesarskim Bukoleon), a część została wywieziona do Europy Zachodniej, głównie do Wenecji. Po upadku cesarstwa łacińskiego na Wschodzie (1264) biblioteki naukowe Konstantynopola ponownie wznowiły działalność w oparciu o zasoby, które ocalały. Nadal były one bardzo obszerne. Na czoło wśród uczelni Konstantynopola wysunęła się wówczas biblioteka akademii Athenaeum. Znajdowały się w niej liczne rękopisy związane z medycyną i farmacją, spisane po łacinie i grecku. Prowadzono tu bowiem wykłady $z$ tych dziedzin nauki.

Po zajęciu Konstantynopola przez Turków w 1453 r. i przekształceniu miasta $\mathrm{w}$ stolicę muzułmańskiego Imperium Osmańskiego zgromadzone w czasach bizantyjskich zbiory rękopisów naukowych stały się podstawą rozwoju nauki tureckiej. W pomieszczeniach zajmowanych wcześniej przez akademię Athenaeum sułtan Sultan Ahmet powołał islamską szkołę wyższą, która przejęła bardzo obszerną, zgromadzoną w czasach bizantyjskich bibliotekę. Druga wyższa uczelnia w Stambule powstała wkrótce w meczecie Fatih, wybudowanym na gruzach bizantyjskiego kościoła św. Apostołów. W obu uczelniach utworzono szkoły kopistów, a zgromadzone w ich bibliotekach dzieła naukowe tłumaczono na język arabski i turecki. Do tłumaczeń wybierano przede wszystkim dzieła o charakterze praktycznym, do których niewątpliwie należały prace starożytnych klasyków medycyny grec- 
Wybrane kolekcje historyczne z zakresu historii medycyny...

kiej i rzymskiej, a także ich średniowiecznych bizantyjskich kontynuatorów.

W przejętych przez tureckie instytucje naukowe bibliotekach bizantyjskich było $\mathrm{w}$ XV w. wiele przetłumaczonych na grekę i łacinę dzieł autorów islamskich, cieszących się uznaniem wśród uczonych europejskich, np. Awicenny. Stworzyło to podstawy dla ukształtowania się w końcu XV w. standardu oficjalnej medycyny i farmacji tureckiej, opartego na podstawach zachodnioeuropejskiej medycyny klasycznej, poddanych już wcześniej interpretacji przez muzułmanów. Standard medycyny starożytnej, greckiej i rzymskiej, już wcześniej, bo VII w., został przyswojony przez uczonych arabskich, którzy uznali go za znacznie bardziej rozwinięty pod względem teoretycznym i efektywniejszy terapeutycznie niż standard rodzimy, wywodzący się z praktyk leczniczych społeczności zamieszkujących arabskie pustynie (tzw. medycyna proroka). Akceptacja islamskich najwyższych instytucji religijnych i władz państwowych dla szerokiej recepcji klasycznego, europejskiego standardu medycyny spowodowała, że bez przeszkód upowszechniał się on w muzułmańskich instytucjach naukowych i był podstawą praktyki lekarskiej kierowanej do ludności zamożnej i zamieszkałej w miastach. Był także podstawą wielu rozwiązań prawnych dotyczących kwestii sanitarnych, regulujących dostęp do wody pitnej czy gromadzenie i usuwanie nieczystości, w których nawiązywano do wzorców prawnych wypracowanych w tym zakresie w starożytnym Rzymie. W pozostających pod władzą muzułmańskich państw miastach tworzono uczelnie, w których nauczano medycyny i farmacji (zwanej materią medyczną) w eklektycznym standardzie łączącym podstawy grecko-rzymskie $\mathrm{z}$ ich uzupełnieniami dodawanymi przez rodzimych uczonych. Największe miasta muzułmańskie, takie jak Bagdad i Kordoba, stały się wielkimi ośrodkami tłumaczeń na język arabski klasycznych, greckich i rzymskich, oraz współczesnych, bizantyjskich dzieł medycznych.

Nie było więc niczym nadzwyczajnym, że po podboju Konstantynopola przez Turków członkowie dynastii osmańskiej wybrali dla stworzenia podstaw medycyny tureckiej tę samą drogę. Od $1453 \mathrm{r}$. do początków XIX stulecia klasyczny grecko-rzymski standard medycyny, z dodawanymi później uzupełnieniami, był uznawany w Imperium Osmańskim za obowiązujący. Przez cztery stulecia wykonano w Stambule, w specjalnie utworzonych szkołach kopistów, setki tysięcy kopii starożytnych dzieł klasyków medycyny, z uzupełnieniami i komentarzami ich średniowiecznych kontynuatorów. Kopie te były 
sprzedawane do meczetów położonych na terenie całego Imperium Osmańskiego, gdzie stawały się podstawą wiadomości dotyczących zdrowia i choroby, diety i profilaktyki, przekazywanych wiernym przez duchownych muzułmańskich. Przyczyniły się do upowszechnienia standardu humoralnego wśród wszystkich wykształconych mieszkańców Imperium Osmańskiego, niezależnie od ich narodowości. Zapoznawali się z nim systematycznie w trakcie cotygodniowych wizyt w meczetach, w których poza praktykami religijnymi oferowano wiernym podstawy edukacji w wielu dziedzinach, $w$ tym edukacji zdrowotnej. Popularyzowanie standardu humoralnego przez muzułmańskich duchownych, odbywające się w świątyniach tego wyznania, sprzyjało temu, że był przez wiernych traktowany poważnie. Sprzyjał też zachowywaniu książek rękopiśmiennych, które wykorzystywano w celu jego popularyzacji, napisanych w języku arabskim i tureckim. Wiele z nich można $\mathrm{z}$ tego powodu znaleźć nie tylko w stolicy dawnego Imperium Osmańskiego - Stambule, lecz także w małych ośrodkach prowincjonalnych, bardzo od tej stolicy odległych, w których znajdowała się muzułmańska świątynia, a nie tylko w większych miastach, w których meczety prowadziły także szkoły koraniczne na poziomie zbliżonym do europejskich uniwersytetów.

Przedstawiona powyżej sytuacja spowodowała, że w Turcji nie upowszechniła się w czasach nowożytnych sztuka drukarska, a książki medyczne do XIX w. były tworzone i rozpowszechniane w formie rękopisów. Pierwsza maszyna drukarska została wprawdzie uruchomiona w Stambule już w $1493 \mathrm{r}^{38}$, ale nie powstało jeszcze wówczas w państwie tureckim większe zapotrzebowanie na wydawane na miejscu druki, o skali porównywalnej do europejskiej. Nauczanie medycyny i farmacji odbywało się bowiem, jak już wyżej wspomniałam, na podstawie rękopiśmiennych książek, które były ilustrowane także ręcznie. Ich liczba była wystarczająca wobec potrzeb. Sułtani sprowadzali wprawdzie już w XVI w. do swoich bibliotek pałacowych niektóre drukowane dzieła medyczne z Zachodu (np. pracę Vesaliusza o anatomii), rekomendowane im jako wartościowe przez praktykujących w Stambule europejskich lekarzy lub tureckich ambasadorów w Europie, ale podstawą stambulskich zbiorów bibliotecznych do XIX w. pozostawały rękopisy. W licznych pracowniach kopiujących książki rękopiśmienne rozwijana była w XV-XVIII w. sztuka kaligrafii oraz tworzenia stylizowanych ilustracji o tematyce medycznej, ułatwiają-

${ }^{38}$ Była własnością Żyda, który przybył do Turcji z Hiszpanii, chroniąc się przed prześladowaniami Inkwizycji. 
Wybrane kolekcje historyczne z zakresu historii medycyny...

cych naukę zawodu przyszłym lekarzom. Ze względu na schematyczny charakter tych ilustracji możliwe było ich wykorzystanie w celach dydaktycznych wyłącznie z odpowiednim komentarzem udzielanym przez nauczyciela zawodu lekarskiego. W kopiowanych w Stambule między XV a początkiem XIX w. rękopisach medycznych spotykamy wiele tego typu barwnych miniatur medycznych, odzwierciedlających ówczesne przekonania dotyczące anatomii i fizjologii, a także ilustrujących metody leczenia.

Wykonywanie w Stambule po podboju miasta przez Turków w 1453 r. tysięcy kopii greckich i rzymskich średniowiecznych dzieł medycznych, tłumaczonych z greki i łaciny na arabski, a później na turecki, było możliwe, ponieważ w Stambule istniała liczna grupa cudzoziemców, z której można było rekrutować potencjalnych tłumaczy, i z której faktycznie ich rekrutowano. Po podboju miasta przez Turków pozostało $\mathrm{w}$ nim wielu Włochów, szczególnie wywodzących się z Wenecji i Genui. W latach 90. XV w. do Turcji napłynęło wielu hiszpańskich Żydów sefardyjskich, znających zarówno łacinę i grekę, jak i język arabski. Sułtan Bajazyd przyjął wówczas ok. 200 tys. imigrantów z Hiszpanii, chroniących się przed prześladowaniami po zakończeniu istnienia ostatnich państw muzułmańskich na Półwyspie Iberyjskim. W XV-wiecznym Stambule mieszkało kilkadziesiąt tysięcy innowierców, w tym: chrześcijan ortodoksyjnych, katolików, wyznawców kościołów ormiańskiego i koptyjskiego oraz wyznawców judaizmu. W XVI w. Stambuł stał się wielkim ośrodkiem tłumaczeń i kopiowania dzieł medycznych, o skali porównywalnej do średniowiecznej roli Bagdadu i Kordoby.

W 1509 r. miało miejsce w Stambule potężne trzęsienie ziemi, które spowodowało tsunami. Wysoka fala zniszczyła tysiące domów mieszkalnych, zabytkowych budowli oraz wiele bibliotek. Znajdowały się one w dawnych chrześcijańskich kościołach przekształconych po 1453 r. na meczety. W 1509 r. uległo zniszczeniu ok. 100 spośród nich, szczególnie te położone nad Bosforem. Zniszczenia centrum miasta zainicjowały w Stambule szeroki ruch budowlany, którego efekty możemy oglądać do dzisiaj. W XVI w. zbudowano w centrum Stambułu kilka ogromnych meczetów, m.in. Fetih, Sultan Ahmet i Sulejmanije, przy których założono szkoły (tzw. medresy) i biblioteki. Zgromadzono w nich bardzo obszerne zbiory rękopisów dzieł naukowych, które przetrwały zniszczenie części miasta przez tsunami. Wznowiono też kopiowanie dzieł medycznych w językach arabskim i tureckim, które wykonywano systematycznie do końca XVIII w. 
Przedstawione powyżej uwarunkowania spowodowały, że we współczesnych muzeach, bibliotekach publicznych i placówkach uniwersyteckich Stambułu znajduje się największy na świecie zbiór rękopisów medycznych w języku arabskim i tureckim, dokumentujących recepcję klasycznego, grecko-rzymskiego standardu medycyny i jego dalszy rozwój z udziałem autorów islamskich.

Poważny wpływ na współczesny kształt zbiorów bibliotek i muzeów historii nauki w Stambule miała podjęta na przełomie XVIII i XIX w. przez władze państwowe decyzja o modernizacji rodzimego standardu medycyny uniwersyteckiej i oparciu go na ówczesnych wzorcach zachodnioeuropejskich. Decyzja ta miała ogromne i wymierne skutki praktyczne. Uznanie na przełomie XVIII i XIX w. starożytnego standardu medycyny humoralnej za przestarzały i niepełny spowodowało zamknięcie istniejących w Stambule licznych pracowni wykonujących odręczne kopie medycznych i farmaceutycznych manuskryptów. Zatrudnionych w nich pracowników zwolniono, pozostawiając ich bez środków do życia. Nie było już bowiem dalszego zapotrzebowania na ich pracę. $W$ tej sytuacji znajdujące się $\mathrm{w}$ magazynach tych pracowni książki uznano za bezwartościowe i przeznaczono do likwidacji. Część z nich właściciele pracowni sprzedali na opał, a część - jako bezużyteczną - wyrzucili. Materiały z pracowni okazały się jednak użyteczne dla ich dawnych pracowników. Wyrywali z nich strony, na których umieszczone były ilustracje, i oferowali je na sprzedaż na targach. $\mathrm{Z}$ początku czynili to bez powodzenia, ponieważ w kulturze islamskiej istnieje zakaz przedstawiania na obrazach ludzkich postaci. Miniatury medyczne nie mogły więc trafić do rodzimych prywatnych kolekcjonerów, którzy nie byli nimi zainteresowani. W końcu XVIII i w pierwszych dwóch dekadach XIX w. pojawiło się jednak w Stambule wielu obcokrajowców, którzy zainteresowali się kolorowymi ilustracjami z tureckich rękopisów medycznych jako oryginalnymi pamiątkami. Ich cena zaczęła w związku z tym stopniowo wzrastać, a same ilustracje bywały oferowane nabywcom w coraz większym wyborze. Posiadający odpowiednie umiejętności techniczne kopiści zamiast wyrzucać dawne manuskrypty medyczne, zaczęli bowiem wycinać $\mathrm{z}$ nich niezapisane strony, a nawet ich fragmenty, i umieszczali na nich kopie dawnych miniatur medycznych, które potrafili malować sami. Sztuka wykonywania miniatur medycznych przetrwała w tej postaci do czasów współczesnych. W drugiej połowie XIX w., gdy nauczanie medycyny i farmacji w Turcji zaczęło się odbywać już wyłącznie na podstawie książek drukowanych i powstały pierwsze instytucje muze- 
alne gromadzące rękopiśmienne zbiory dzieł naukowych, miniatury medyczne będące do nich ilustracjami zyskały w Turcji status dzieł sztuki. Współcześnie w zbiorach tych instytucji znajdują się bardzo liczne miniatury medyczne, będące ilustracjami do dzieł naukowych napisanych w standardzie patologii humoralnej. Miniatury te zostały wykonane przeważnie w XVII i XVIII w. na podstawie rękopisów pochodzących z okresu od XII do XVIII w. W kolekcjach muzealnych znajdują się także miniatury medyczne wykonane w XIX w. - już po zmianie standardu stambulskich uczelni medycznych i jego modernizacji według wzorców zachodnioeuropejskich, a także w XX w. Kopie dawnych miniatur medycznych wykonywane są także współcześnie. Mają status dzieł sztuki kaligraficznej i wystawiane są w specjalnie im poświęconych ekspozycjach. Jedna z nich jest np. własnością fundacji związanej z Uniwersytetem w Bursie. Liczne miniatury posiada także Muzeum Sztuki Tureckiej i Islamskiej, utworzone w dawnym pałacu Ibrahima Paszy (wezyra sułtana Sulejmana Wspaniałego) w Stambule. Muzeum zostało założone w $1984 \mathrm{r}$. i posiada w swoich zbiorach liczne rękopisy powstałe między VIII a XIX w., w tym ilustrowane rękopisy medyczne.

Od lat 20. XIX w. tworzy się w Turcji nowa część współczesnego korpusu muzeów i kolekcji o tematyce związanej z historią medycyny i farmacji. Są to książki drukowane, wykorzystywane jako podręczniki w tworzonych w Stambule szkołach o tym profilu, a także wykorzystywane w edukacji studentów i praktyce szpitalnej sprzęty. Większą część tych książek wydrukowano w Europie Zachodniej, są napisane $\mathrm{w}$ językach niemieckim, francuskim i angielskim. Dopiero w latach 60. XIX w. pojawiają się w zasobie bibliotecznym książki z dziedziny medycyny i farmacji napisane po turecku.

W 1827 r. założono w Stambule szkołę medyczną (Tibbiye) z europejskim programem nauczania. W 1839 r. powstała podobna uczelnia o profilu farmaceutycznym. W 1863 r. obie te szkoły włączono do nowo założonego uniwersytetu, zwanego Dom Nauk, prowadzącego nauczanie w zakresie nauk ścisłych. W $1870 \mathrm{r}$. zmieniono nazwę tej uczelni na Uniwersytet Osmański. W 1874 r. uruchomiono na nim studia humanistyczne. W 1912 r. nazwę uczelni zmieniono po raz kolejny - na Uniwersytet Stambulski i rozpoczęto jego forsowną reorganizację, uwzględniającą najnowsze zdobycze fizyki, chemii, biologii i medycyny, w tym bakteriologię. Aż do upadku Imperium Osmańskiego Uniwersytet Stambulski miał status szkoły prywatnej. W 1924 r., rok po powstaniu Republiki Tureckiej, Uniwersytet Stambulski upań- 
stwowiono, by umożliwić jego dalszą modernizację według wzorów zachodnioeuropejskich. W 1925 r. utworzono Bibliotekę Uniwersytecką. Przeniesiono do niej ponad 20 tys. rękopisów o ogromnej wartości naukowej i historycznej. Nie są one jednak szeroko dostępne dla zwiedzających. Dostęp do nich mają wyłącznie pracownicy naukowi i studenci, po uzyskaniu formalnego zezwolenia. Biblioteka Uniwersytetu Stambulskiego gromadzi współcześnie ponad 250 tys. tomów, z których wiele dokumentuje historię medycyny XIX i XX w. Cenne kolekcje starych książek drukowanych mają także biblioteki Wydziału Lekarskiego i Wydziału Farmaceutycznego tej uczelni. Są one udostępniane na tych samych zasadach, co opisane wyżej.

Kolejnym etapem kształtowania korpusu zasobów bibliotecznych w Stambule, mających obecnie status zabytków, są lata 30. XX w. Emigranci z III Rzeszy, lekarze, farmaceuci, a także uczeni prowadzący działalność naukową w obszarze nauk podstawowych wobec medycyny i farmacji (biologii, botaniki, farmakognozji, chemii farmaceutycznej itp.) przywieźli ze sobą do Turcji bogate księgozbiory fachowe. Do 1939 r. inspirowali też zakup do tureckich bibliotek naukowych najnowszej literatury naukowej, którą uznawali za wartościową, zarówno książek, jak i czasopism naukowych. Z omawianego okresu pochodzi wiele albumów i tablic poglądowych (np. anatomicznych). Bardzo cenną kolekcją, której powstanie zostało zainicjowane właśnie w tym okresie, dysponuje Ogród Botaniczny Wydziału Farmaceutycznego. Znajdują się w nim albumy i ręcznie malowane atlasy roślin leczniczych, zielniki, zbiory nasion. Powstały one już na miejscu, w Stambule, przy udziale emigrantów z Niemiec jako nauczycieli tureckich studentów. Zbiory dawnych książek medycznych i czasopism specjalistycznych o zachodnioeuropejskim rodowodzie mogą być podstawą do badań nad recepcją europejskiego standardu medycyny i farmacji w Turcji.

Największa z wyższych uczelni w Stambule prowadzących nauczanie w zakresie historii medycyny i farmacji, Uniwersytet Stambulski, podkreśla swoje XV-wieczne dziedzictwo. Pomimo tego, że Uniwersytet ten został w sposób formalny utworzony dopiero w $1863 \mathrm{r}$., to w Turcji uznaje się tę uczelnię za bezpośrednią kontynuację szkoły islamskiej (medresy) założonej w 1453 r. na terenie dawnej bizantyjskiej uczelni Athanaeum. Biblioteka Uniwersytetu Stambulskiego posiada jedną z największych na świecie kolekcji rękopisów medycznych, w tym manuskryptów ilustrowanych miniaturami o tematyce medycznej. Są one zgromadzone zarówno w centralnych zbiorach 
Wybrane kolekcje historyczne z zakresu historii medycyny...

tej uczelni, jak i w bibliotekach Wydziałów Lekarskiego i Farmaceutycznego, a także w Muzeach Historii Farmacji wchodzących w skład struktury tych muzeów.

Kolekcje zbiorów związanych z historią medycyny i farmacji zaczęły w XIX w. gromadzić także inne tureckie wyższe instytucje edukacyjne. W 1883 r. został założony w Stambule Uniwersytet Marmara. Wyposażono go w obszerną bibliotekę, w której znalazła się pokaźna kolekcja rękopisów i starodruków medycznych pochodzących z różnych źródeł. Dzieła te znajdują się obecnie w Bibliotece Wydziału Medycyny i Nauk o Zdrowiu, mieszczącej się w centralnym kompleksie tego uniwersytetu - Kampusie Göztepe ${ }^{39}$.

W 1884 r. powstała kolejna biblioteka naukowa w Stambule, zlokalizowana w kompleksie meczetu Bajazyda, pochodzącym z XVI w. Zgromadzono w niej ogromny zbiór rękopisów i książek drukowanych, a także czasopism naukowych, popularnych i dzienników z czasów Imperium Osmańskiego. Współcześnie biblioteka meczetu Bajazyda gromadzi także bardzo obszerne zbiory druków z pierwszych lat Republiki Tureckiej. Zbiory znajdują się w trakcie digitalizacji. Część $\mathrm{z}$ nich jest już dostępna w internecie. Państwowa Biblioteka Bajazyda jest instytucją państwową, utrzymywaną ze środków budżetowych.

Obszerne zbiory rękopisów i starodruków posiada także Biblioteka Publiczna Orhana Kemala, zlokalizowana w budynku z czasów Mehmeta II Zdobywcy, tj. z XV w. Korzystanie z oryginałów jest jednak niemożliwe bez specjalnego zezwolenia. Niektóre z nich można oglądnąć w specjalnych warunkach i w rękawiczkach, w wydzielonych pomieszczeniach i w obecności personelu, po uzyskaniu zgody dyrekcji tych placówek.

W 1918 r. na terenie meczetu Sulejmana w Stambule utworzono Bibliotekę Sulejmaniye, do której przeniesiono zbiory pochodzące m.in. z bibliotek należących wcześniej do osób prywatnych i islamskich instytucji religijnych. Biblioteka posiada obecnie największą i najbardziej znaczącą kolekcję manuskryptów islamskich na świecie. Znajdują się tu m.in. rękopisy prac znanego średniowiecznego lekarza Awicenny i wielu innych autorów związanych z obszarem medycyny i farmacji ${ }^{40}$. Obok oryginalnych manuskryptów, ich odpisów i rękopiśmiennych komentarzy do nich biblioteka gromadzi także wydania krytyczne. Wiele $\mathrm{z}$ nich jest wydanych $\mathrm{w}$ podwójnej wersji językowej: $w$ oryginale $w$ języku arabskim, tureckim czy perskim i w tłu-

\footnotetext{
${ }^{39}$ Por. E. Piotrowska, R.M. Zając, op. cit., s. 1.

${ }^{40}$ Ibidem.
} 
maczeniu na jeden z języków europejskich, najczęściej angielski lub niemiecki. Wybór tych wersji językowych wynika z zainteresowania muzułmańskimi rękopisami medycznymi z różnych epok wyrażanego przez uczonych amerykańskich i niemieckich, którzy podejmują nad nimi studia. Wydania krytyczne dzieł autorów muzułmańskich, opublikowane $\mathrm{w}$ oryginale oraz po angielsku lub niemiecku, publikowane są także przez autorów tureckich i pochodzących z różnych krajów islamskich, odbywających studia doktoranckie lub zdobywających stopnie naukowe w USA lub w Niemczech.

O specyfice stambulskich zasobów bibliotecznych grupujących prace rękopiśmienne i drukowane z czasów Imperium Osmańskiego, związanych tematycznie z historią medycyny i farmacji, decyduje fakt, że język turecki stał się językiem wykładowym tureckich wyższych instytucji edukacyjnych dopiero $\mathrm{w} 1866 \mathrm{r}^{41}$ Wykładowcami medycyny i farmacji byli wcześniej, tj. od początku procesu modernizacji medycyny tureckiej według współczesnych wzorców zachodnioeuropejskich, uczeni zachodnioeuropejscy, głównie Francuzi, Austriacy i Niemcy. Sprowadzali oni dużą liczbę dzieł naukowych i praktycznych, np. farmakopee, $\mathrm{z}$ których korzystali. Podobna sytuacja miała miejsce także w innych wyższych szkołach medycznych na terenie Imperium Osmańskiego. Przykładowo, szkoła medyczna w Kairze uruchomiona została w ten sposób, że władze wytypowały osoby chętne do podjęcia studiów medycznych we Francji, które byłyby gotowe po powrocie (w zamian za udzielone stypendium) podjąć pracę asystentów profesorów sprowadzonych do Egiptu z Francji. Profesorowie wykładali w pierwszym okresie po francusku, a ich egipscy asystenci pomagali swoim rodakom zrozumieć ich wykłady. Dopiero po kilkunastu latach, gdy asystenci nabrali zawodowego doświadczenia, rozpoczęto edukację w języku arabskim.

Dawne książki medyczne o europejskim rodowodzie są współcześnie znaczącą częścią tureckich działów starodruków w stambulskich bibliotekach naukowych. Dokumentują głównie kształtowanie się wzajemnych relacji między medycyną turecką a niemiecką, francuską i angielską, a także trwałość przyjętego w Turcji w XV w. modelu kształtowania rodzimego standardu nauk przyrodniczych: oparcia go na wzorcach zagranicznej praktyki naukowej i rozwijaniu ich w sposób twórczy w ramach rodzimej praktyki naukowej. Zarówno w XV, jak i XVIII oraz XX w. utrzymano zasadę dążenia do ujednolicenia teoretycznych podstaw tureckiej medycyny $\mathrm{i}$ farmacji $\mathrm{z}$ regułami

${ }^{41}$ Por. J. Musiatewicz, op. cit., s. 84. 
Wybrane kolekcje historyczne z zakresu historii medycyny...

kształtującymi podstawy tych nauk w Europie Zachodniej. Profil medycyny i farmacji w Turcji jest zarazem wyraźnie odrębny od rodzimego standardu lecznictwa ludowego, opartego na uzdrawianiu, oraz różnych metod leczenia o standardzie paranaukowym.

\section{Kształtowanie się wzorców wystawienniczych w Turcji pod wpływem europejskiego modelu muzealnictwa}

W drugiej połowie XIX w. zaczął się w Turcji kształtować współczesny standard muzealny. Impulsem dla jego rozwoju były wzorce francuskich i angielskich muzeów imperialnych, mieszczących się w Paryżu i Londynie. W 1869 r. sułtan Abdülaziz postanowił powołać tego rodzaju centralne muzeum w Stambule. Na jego siedzibę wyznaczył pochodzący z IV w. kościół św. Ireny, znajdujący się w obrębie kompleksu pałacowego Topkapı, dawnej siedziby władców Turcji. W początkach XIX w. sułtani przenieśli się wraz z całym dworem do nowej rezydencji, pałacu Dolmabahcze nad Bosforem. Stary kompleks pałacowy, położony w centrum miasta, mógł zostać przeznaczony na cele muzealne. Do kościoła św. Ireny przeniesiono w 1869 r. pierwsze zbiory, które nie były jednak udostępniane publiczności. Kościół miał bowiem charakter magazynu muzealnego. Ze względu na niezbyt duże rozmiary nie nadawał się bowiem do wykorzystania w celach wystawienniczych. Pierwszym kuratorem nowo powstałego Muzeum Archeologicznego w Stambule był angielski nauczyciel liceum w pobliskiej dzielnicy Galatasaray - Edward Goold. W 1872 r. muzeum zostało jednak zamknięte $\mathrm{z}$ powodu braku funduszy na dalszą działalność, a być może także z powodu zmiany koncepcji jego prowadzenia. Już bowiem w końcu 1872 r. działalność muzeum wznowiono. Na dyrektora powołano Niemca - Philippa Antona Dethiera, archeologa i historyka, który kierował placówką do swojej śmierci (1881). Zmiana ta nie była przypadkowa, wiązała się z coraz ściślejszym sojuszem turecko-niemieckim, rozwijanym nie tylko w obszarze nauki i kultury, lecz przede wszystkim polityki. Po zjednoczeniu Niemiec władze tureckie uznały bowiem Cesarstwo Niemieckie za swojego głównego europejskiego partnera.

W 1881 r. dyrektorem Muzeum Archeologicznego w Stambule został Osman Hamdi Bey. Przy finansowym wsparciu sułtana podjął decyzję o zbudowaniu $\mathrm{w}$ dawnym kompleksie pałacu Topkapı, w przylegającym do jego murów parku Gülhane, nowego, okazałego budynku muzealnego w europejskim stylu. W 1883 r. rozpoczęto budowę Muzeum Archeologicznego według projektu francuskiego archi- 
tekta Alexandra Vallamy'ego. W 1891 r. Muzeum zostało ukończone i otwarte dla zwiedzających. Był to największy budynek w Stambule w stylu neoklasycyzmu. Już wkrótce obiekt ten okazał się jednak za mały. W 1903 r. podjęto jego rozbudowę, dodając do gmachu dwa dodatkowe skrzydła. Umieszczono w nim ponad milion eksponatów, wystawionych według najnowocześniejszych wtedy wzorców wystawienniczych w Europie. Placówka zatrudniła wielu pracowników, stając się podstawą upowszechnienia profesjonalnego wystawiennictwa w Turcji. W 1916 r. funkcję kustosza objął niemiecki archeolog Eckhard Unger. Pracował w Stambule do 1918 r., a następnie w latach 1924-1925 i 1932-1933. Był pierwszym doktorem habilitowanym (habilitował się w 1924 r. w Berlinie) pełniącym funkcję Dyrektora Departamentu Orientalnego Muzeum Archeologicznego w Stambule.

Omawiane tu inspiracje niemieckie wywarły zasadniczy wpływ na turecki standard wystawienniczy w całym XX i w pierwszych dekadach XXI w., także w dziedzinie historii medycyny i farmacji. Za najważniejsze elementy tego standardu należy uznać:

1) oparcie ekspozycji na autentycznych zabytkach $z$ dawnych epok historycznych (lub ich kopiach), a nie przede wszystkim na planszach lub instalacjach interaktywnych;

2) dążenie do aranżacji wnętrz muzealnych zgodnie $z$ wyraźnie sformułowanym planem/scenariuszem;

3) sformułowanie celu wystawy, którego realizację ów plan/scenariusz umożliwia.

W niektórych ekspozycjach muzealnych ten cel i mający przybliżyć jego realizację plan/scenariusz jest przedstawiany przez kuratorów wystaw w przewodnikach. Gdy takich przewodników brak, wystawa powinna być tak skonstruowana, by umożliwić zwiedzającym prawidłowe odczytanie scenariusza przedstawianej ekspozycji przez sposób aranżacji eksponatów oraz ich dobór. Wskazana tu metoda organizacji wystaw historycznych miała w początkach XX w. w Turcji charakter pionierski i nowatorski. Wcześniej prywatne kolekcje różnego rodzaju zabytków nie były bowiem opracowywane według jakiegoś szczególnego planu. Ich rozmieszczenie podporządkowywano ogólnej estetyce danego wnętrza lub obiektu, a nie konstruowano w sposób zamierzony, związany z tematyką danej ekspozycji. Opisany tu standard znajduje swoje odbicie także we współczesnych stambulskich ekspozycjach związanych pod względem tematycznym z historią medycyny i farmacji.

W drugiej części artykułu zostaną przedstawione wybrane przykłady realizacji tego standardu. 
Wybrane kolekcje historyczne z zakresu historii medycyny...

\section{Bibliografia}

Alkan E., Current Reflections of the Turkish Bath Culture, [w:] A. Namal, A.D. Erdemir, B. Płonka-Syroka (red.), Tarihte saglik ve Su kültürü / Gesundheit und Wasserkultur in der Geschichte / Health and Water-Culture in History, Istanbul Medical Saglik ve Yayincilik Hiz. Tic. Ltd., Istanbul 2016.

Anagnostu S., From East to West: Creation, Transmission and Development of Phyto-Pharmaceutical Knowledge over the Centuries, [w:] A. Mat, H. Tekiner, B. Sen (red.), The Exchgange of Pharmaceutical Knowledge between East and West. Proceedings 42nd International Congress for the History of Pharmacy 8-11 September 2015 Istanbul, Maestro Advertising Co., Istanbul 2016.

Armstrong K., Krótka historia islamu, tłum. J. Włodarczyk, Wydawnictwo Dolnośląskie, Wrocław 2004.

Baran D., Turkish Baths in the Romanian Principalities, [w:] A.D. Erdemir, S. Erer, Ő. Usmanbas, B. Akgün (red.), 5th Balkan Cobgress on the History \& Ethics of Medicine 11-15 October 2011 Istanbul. Abstracts and Proceedings Book, Nobel Tip Kitabevleri Ltd., Istanbul 2012.

Cantay G.G., Hammam - Thermal Spring (Terms, Architectuce, Bathing, Healing), [w:] A. Namal, A.D. Erdemir, B. Płonka-Syroka (red.), Tarihte saglik ve Su kültürü / Gesundheit und Wasserkultur in der Geschichte / Health and Water-Culture in History, Istanbul Medical Saglik ve Yayincilik Hiz. Tic. Ltd., Istanbul 2016.

Ceykan D., Sevumli S., Some Examples of „Multinational” Charaktr of Ottoman Medical Education and Service, [w:] A.D. Erdemir, S. Erer, Ö. Usmanbas, B. Akgün (red.), 5th Balkan Congress on the History \& Ethics of Medicine 11-15 October 2011 Istabul. Abstracts and Proceedings Book, Nobel Tip Kitabevleri Ltd., Istanbul 2012.

Cremer J., Przytula H., Exil Türkey. Deutschsprächige Emigranten in der Türkey 1933-1945, München b.r.

Czajkowska A., Doświadczenie Wschodu w XVIII i XIX wieku w biografiach kobiet (na przykładzie Salomei Pilsztynowej, Ludwiki Śniadeckiej i Jadwigi Zamojskiej), „Pamiętnik Literacki” 2018, R. CIX, z. 2.

Dramur R., The Medicine Chest in the National Palace at Dolmabahce, [w:] 12nd International Congress on the Turkish History of Medicine 10-13 December 2021 Istanbul, Istanbul University, 2013.

Dramur R., La pratique de la Pharmacie et de la médecine au 19éme siècle aux palais de l'Empire Ottoman, [w:] A. Mat, H. Tekiner, 
B. Sen (red.), The Exchgange of Pharmaceutical Knowledge between East and West. Proceedings 42nd International Congress for the History of Pharmacy 8-11 September 2015 Istanbul, Maestro Advertising Co., Istanbul 2016.

Erbay F., Istanbul Exhibitions as a Rescue for the History of Medicine, [w:] A.D. Erdemir, S. Erer, Ő. Usmanbas, B. Akgün (red.), 5th Balkan Cobgress on the History \& Ethics of Medicine 11-15 October 2011 Istanbul. Abstracts and Proceedings Book, Nobel Tip Kitabevleri Ltd., Istanbul 2012.

Erbay F., The Role of Medical Museum in the Education of Medicine, [w:] A. Musajo-Somma (red.), The 39th International Society of History of Medicine Congress on the History of Medicine 5-10 September 2004, Italia, Bari 2005.

Gültekin E., Geschichte der modernen Hydrotherapie in der Türkey mit einigen originalen Beiträgen, [w:] A. Namal, A.D. Erdemir, B. Płonka-Syroka (red.), Tarihte saglik ve Su kültürü / Gesundheit und Wasserkultur in der Geschichte / Health and Water-Culture in History, Istanbul Medical Saglik ve Yayincilik Hiz. Tic. Ltd., Istanbul 2016.

Haarmann U., Bachmann P. (red.), Die islamische Welt zwischn Mittelalter und Neuzeit. Festschrift für Hans Robert Roemer zum 65 Geburtstag, Ergon Verlag, Beirut-Wiesbaden 1979.

Imber C., Imperium Osmańskie 1300-1650, tłum. P. Zarawska, Wydawnictwo Naukowe PWN, Kraków 2018.

Kaiogu F.G., Nazik S., Kadioglu S., Antakyali bilge hekimin Hamam kitabi, Büyüksehir Belediyesi Yayinlari, Hatay 2018.

Kernbauer A., Die Beziehungen österreichischer Universitäten, im besonderen jener von Prag und Graz, zur Universität Istanbul, [w:] A. Terzioglu (red.), Proceedings of the Internationl Symposium: Istanbul University and the European Universities on the Occasion ot the 550th Anniversary of the Foundation of Istanbul University, University of Istanbul, Istanbul 2004.

Kottek S.S., Maimonides (1138-1204) über Naturheilkunde, [w:] C.-P. Heidel (red.), Naturheilkunde und Judentum. Medizin und Judentum, t. 9, Mabuse Verlag, Frankfurt am Main 2008.

Kotynia O., Lekarstwa stosowane w medycynie proroka, [w:] B. Płonka-Syroka, Ł. Braun (red.), Kultura medyczna islamu, Wydawnictwo DiG, Warszawa 2015.

Kompa A., Konstantynopolitańskie zabytki w Stambule, „Acta Universitatis Lodzensis. Folia Historica” 2011, z. 87. 
Wybrane kolekcje historyczne z zakresu historii medycyny...

Z Kosmowskich-Krajewska T., Pamiętnik, przygotowała do druku H. Czajecka, Kraków 1989.

Kyrkoudis Th., Soteriadu C., Pharmacy at the Crossroads of Trade, Science and Civilisation in Istanbul, [w:] A. Mat, H. Tekiner, B. Sen (red.), The Exchgange of Pharmaceutical Knowledge between East and West. Proceedings 42nd International Congress for the History of Pharmacy 8-11 September 2015 Istanbul, Maestro Advertising Co., Istanbul 2016.

Lafont O., Greek Science at the Centre of the Dialoque between Orient and Occident, [w:] A. Mat, H. Tekiner, B. Sen (red.), The Exchgange of Pharmaceutical Knowledge between East and West. Proceedings 42nd International Congress for the History of Pharmacy 8-11 September 2015 Istanbul, Maestro Advertising Co., Istanbul 2016.

Legowicz J., Historia filozofii średniowiecznej Europy zachodniej, Państwowe Wydawnictwo Naukowe, Warszawa 1980.

Lemaire G.-G., Orientalismus. Das Bild des Morgenlands in der Malerei. Mit einem Vorwort von Geneviéve Lacambre, Tandem Verlag, Potsdam 2010.

Lewicka P.B., Medicine for Muslims? Islamic Theologians, Non-Muslim Physicians and the Medical Cultur of th Mamluk Near East, "Annemarie Schimmel Kolleg Working Paper" 2012, nr 03.

Łątka J.S., Odaliski, poturczeńcy i uchodźcy. Z dziejów Polaków w Turcji, Wydawnictwo Universitas, Kraków 2001.

Łątka J.S., Słownik Polaków w Imperium Osmańskim i Republice Turcji, wyd. 2 poprawione i uzup., Wydawnictwo Towarzystwo Słowaków, Kraków 2015.

Maimonides, On Asthma. A Paralell Arabic-English text edited, translated and annotated by Gerrit Bos, Young University Press, Brigham 2002.

Mayer H.E., Historia wypraw krzyżowych, tłum. T. Zatorski, Biblioteka Historii Kościoła, Wydawnictwo WAM, Kraków 2008.

Mazaheri A., Życie codzienne muzułmanów w średniowieczu (wiek $X-X I I I)$, tłum. E. Bąkowska, Państwowy Instytut Wydawniczy, Warszawa 1972.

Mönnich M.W., Drug Therapy and Rhazes (865-925): Cultural Heritage and Innovation, [w:] A. Mat, H. Tekiner, B. Sen (red.), The Exchgange of Pharmaceutical Knowledge between East and West. Proceedings 42nd International Congress for the History of Pharmacy 8-11 September 2015 Istanbul, Maestro Advertising Co., Istanbul 2016. 
Musiatewicz J., Lekarze w czasach przemian. Dziewiętnastowieczni egipscy absolwenci europejskich uczelni medycznych, [w:] B. Płonka-Syroka, Ł. Braun (red.), Kultura medyczna islamu, Wydawnictwo DiG, Warszawa 2015.

Mutlu S., Michel S., Une Collection de Matiere Medicale Ottomane au Sein d'un Musee Universitaire a Paris, [w:] A. Mat, H. Tekiner, B. Sen (red.), The Exchgange of Pharmaceutical Knowledge between East and West. Proceedings 42nd International Congress for the History of Pharmacy 8-11 September 2015 Istanbul, Maestro Advertising Co., Istanbul 2016.

Namal A., Beiträge jüdischer Wissenschaftler u den vorklinischen Fächern der Medizin bei der türkischen Universitätsreform von 1933, [w:] A. Scholz, C.P. Heidel (red.), Emigrantenschicksale. Einfluss der jüdischen Emigranten auf Sozialpolitik und Wissenschaft in den Aufnahmeländern, Medizin und Judentum, t. 7, Mabuse-Verlag, Frankfurt am Main 2004.

Namal A., Zwischen Emigration aus dem NS-Einflussbereich und Ankunft in Palästina bzw. Israel: Jüdische Wissenschaftler an der Universität Istanbul, [w:] C.P. Heidel (red.), Der Einfluss des Zionismus auf Medizin und Gesundheitswesen, Medizin und Judentum, t. 8, Mabuse-Verlag, Frankfurt am Main 2006.

Namal A., Emigranten im Gesundheitswesen im Rahmen der türkischen Universitätsreform von 1933, [w:] R. Pfrepper (red.), Medizin-, Pharmazie- und Wissenschaftsgeschichte vom Mittelalter bis zur Gegenwart. Festschrift für Ingrid Kästner zum 65 Geburtstag, Shaker Verlag, Aachen 2007.

Namal A., Die Stellung der Juden in der osmanischen Geschichte der Medizin und Spuren ihrer heilkundischen Tätigkeit, [w:] C.-P. Heidel (red.), Naturheilkunde und Judentum. Medizin und Judentum, t. 9, Mabuse-Verlag, Frankfurt am Main 2008.

Namal A., Die Leipzigerin Dr. Cäcilie Leuchtenberger (geb. Nussenow) übernimmnt eine Stele an der medizinischen Fakulät der Universität Istanbul - Kurzer Zwischenhalt in einem von Migration geprägten Leben, [w:] B. Płonka-Syroka (red.), Człowiek, natura, kultura - studia z historii i antropologii medycyny i farmacji społecznej, Studia Humanistyczne Wydziału Farmaceutycznego Akademii Medycznej we Wrocławiu, t. 2, Wrocław 2009.

Namal A., Turkish baths in history and their place in daily life, [w:] B. Płonka-Syroka, A. Kaźmierczak, S. Jandziś, A. Syroka (red.), Tradycje i perspektywy rozwoju kultury uzdrowiskowej w Iwo- 
niczu-Zdroju w kontekście europejskim, Kultura uzdrowiskowa w Europie, t. 10, Oficyna Wydawnicza Arboretum, Wrocław 2018.

Nicolas M., La Pharmacie d'Officine Ottomane, [w:] A. Mat, H. Tekiner, B. Sen (red.), The Exchgange of Pharmaceutical Knowledge between East and West. Proceedings 42nd International Congress for the History of Pharmacy 8-11 September 2015 Istanbul, Maestro Advertising Co., Istanbul 2016.

Obolenski D., The Byzantine Commonwealth Eastern Europe 5001453, London, Cardinal 1974.

Ojalvo H., Ottoman Sultans and Their Jewish Sobjects, http://www. sephardicstudies.org/sultans1.html.

Özturk H., Turkish Baths in the Travel Book of Evliya Celebi: The City of Istanbul, [w:] A. Namal, A.D. Erdemir, B. Płonka-Syroka (red.), Tarihte saglik ve Su kültürü / Gesundheit und Wasserkultur in der Geschichte / Health and Water-Culture in History, Istanbul Medical Saglik ve Yayincilik Hiz. Tic. Ltd., Istanbul 2016.

Öztürk Y., A Virtual Historical Museum: the Case of Historical Sihhat Pharmacy (Tarihi Sihhat Eczanesi) in the Faculty of Anadolu University, [w:] A. Mat, H. Tekiner, B. Sen (red.), The Exchgange of Pharmaceutical Knowledge between East and West. Proceedings 42nd International Congress for the History of Pharmacy 8-11 September 2015 Istanbul, Maestro Advertising Co., Istanbul 2016.

Pentek Z., Cesarstwo łacińskie 1204-1261. Kolonialne państwo krzyżowców czy Neobizancjum?, Wydawnictwo Poznańskie, Poznań 2004.

Piotrowska E., Zając R.M., Biblioteki w Stambule, „Czasopismo Biblioteki Głównej Uniwersytetu Pedagogicznego w Krakowie” 2015, nr 7.

Płonka-Syroka B., Medycyna islamska $w$ świetle średniowiecznych miniatur medycznych, [w:] B. Płonka-Syroka, Ł. Braun (red.), Kultura medyczna islamu, Wydawnictwo DiG, Warszawa 2015.

Pormann P.E., Savage-Smith E., Medieval Islamic Medicine, Georgetown University Press, Georgetown 2007.

Reisman A., Turkey's Modernization. Refuges from Nazism and Atatürks Vision, Washington DC, 2006.

Z Rusieckich Pilsztynowa S., Proceder podróży i życia mego awantur, redakcja i wstęp R. Pollak, tekst i przypisy przygotował M. Pełczyński, Wydawnictwo Literackie, Kraków 1962.

Said E.W., Orientalizm, tłum. W. Kalinowski, wstęp Z. Żygulski jun., Warszawa 1991. 
Sari N., Hydrotherapy as descripted in Ottoman Medical Manuscripts, [w:] A. Namal, A.D. Erdemir, B.Płonka-Syroka (red.), Saglik ve Su Kültürü / Gesundheit und Wasserkultur / Health and Water-Culture, Birinci Baski, Istanbul 2014.

Savage-Smith E., Medycyna, [w:] R. Rashed (red.), Historia nauki arabskiej, t. 3. Technika, alchemia, nauki przyrodnicze i medycyna, tłum. J. Kozłowska, K. Pachniak, Wydawnictwo Dialog, Warszawa 2005.

Schwartz P., Notgemeinschaft. Zur Emigration deutscher Wissenschaftler nach 1933 in die Türkey, opracowanie i wstęp H. Peukert, Metropolis Verlag, Marburg 1995.

Sen B., Deutsch-Türkische Beziehungen in der Pharmazie, [w:] A. Mat, H. Tekiner, B. Sen (red.), The Exchgange of Pharmaceutical Knowledge between East and West. Proceedings 42nd International Congress for the History of Pharmacy 8-11 September 2015 Istanbul, Maestro Advertising Co., Istanbul 2016.

Sen B., Nicolas M., Mat A., Les Relations Academiques en Pharmacie entre la France et la Turqie, [w:] A. Mat, H. Tekiner, B. Sen (red.), The Exchgange of Pharmaceutical Knowledge between East and West. Proceedings 42nd International Congress for the History of Pharmacy 8-11 September 2015 Istanbul, Maestro Advertising Co., Istanbul 2016.

Sezgin F., The Istanbul Museum for the History of Science and Technology in Islam (An Overview), Culture Co., Istabul 2010.

Shefer-Mossensohn M., Ottoman Medicine: Healing and Medical Institutions, 1500-1700, State University of New York, Albany 2009.

Sinko T., Literatura grecka, t. 3, cz. 2, Wydawnictwo PAU, Kraków 1954.

Stern B., Medizin, Aberglaube und Geschlechtsleben in der Türkey. Mit Berücksichtigung der moslemischen Nachbarländern und der ehemaligen Vasallenstaaten, H. Barsdorf Verlag, Berlin 1903.

Stępniewska-Holzer B., Życie codzienne na Bliskim Wschodzie w XIX wieku, Państwowy Instytut Wydawniczy, Warszawa 2002.

Terzioglu A., Die Verdienste der österreichischen Ärzte, [w:] E. Lesky (red.), Wien und Weltmedizin, Böhlau Verlag, Wien-Köln-Graz 1974.

Terzioglu A., Lucius E. (red.), Österreichisch-Türkische Medizinische Beziehungen. Berichte des Symposiums von 28. und 29. April 1986 in Istanbul, University of Istanbul, Istanbul 1987.

Treatgold W.T., History of Byzantine State and Society, Stanford University Press, 1997. 
Wybrane kolekcje historyczne z zakresu historii medycyny...

Yildirim R., Ulman Y., A Look at the Ottoman Social and Medical Modernization through the Life of Dr. Servicen, „Bulgarian Historical Review” 2013, z. 3-4. 